\title{
MENGUNGKAP KETIDAKADILAN DALAM PRAKTIK PEMBIAYAAN MUDHARABAH: STUDI FENOMENOLOGI
}

\author{
Rachmania Tsabita \\ Iwan Triyuwono \\ M. Achsin \\ Fakultas Ekonomi dan Bisnis Universitas Brawijaya \\ Jl. Mayjen Haryono No. 165 Malang \\ Email: bietaaa@yahoo.com
}

Abstract

The objective of the research is to uncover the injustice in mudharabah financing practice. Qualitative research method with Husserl transcendental phenomenology approach is used to understand, analyze, and describe why the injustice happens. Primary and Secondary data are collected from interview with three credible persons from BMT Al-Rifa'i as mudharib and syariah Bank "X" as shahibul maal. There are three phenomena noted, which are (1) only financial institution is eligible to be mudharib, (2) profit sharing is calculated based on expected yield ascertained in advance, and (3) loss sharing is burdened to mudharib only. It is concluded that the current phenomena of mudharabah financing practice has no difference with conventional financing in term of bank domination, which is indicated by (1) purely profit oriented financing, (2) expected yield is fixed in advance based on bank policy, and (3) standard contract which consider every mudharib has similar situation, condition and problem is implemented.

Keywords: syariah bank, mudharabah financing, injustice

Abstrak

Penelitian ini bertujuan untuk mengungkap fenomena ketidakadilan dalam praktik pembiayaan mudharabah. Jenis penelitian ini adalah kualitatif dengan pendekatan 
fenomenologi transendental Husserl yang bertujuan untuk mengungkap fenomena ketidakadilan dalam pembiayaan mudharabah dan menganalisis serta mendiskripsikan penyebab terjadinya ketidakadilan tersebut. Penelitian ini menggunakan data primer dan sekunder dari BMT Al-Rifa'i sebagai mudharib serta Bank Syariah X selaku shahibul maal. Informan dalam penelitian ini berjumlah tiga orang yang telah diuji kredibilitasnya sebagai informan. Hasil penelitian ini mengungkapkan bahwa ketidakadilan dalam praktik pembiayaan mudharabah: (1) Hanya kepada mudharib yang berbentuk lembaga keuangan saja. (2) Angsuran tetap yang dihitung dari expected yield yang ditetapkan di awal kontrak. (3) Risiko usaha dibebankan sepihak kepada mudharib. Berdasarkan hasil penelitian tersebut, dapat dijelaskan bahwa, praktik pembiayaan mudharabah sejenis dengan kredit usaha pada bank konvensional. Kesamaan tersebut antara lain: (1) Bank dalam praktik pembiayaan mudharabah hanya berorientasi pada laba. (2) Penentuan tingkat keuntungan dalam kekuasaan bank. (3) Bank menerapkan standard contract atau akad baku yang menganggap semua mudharib memiliki situasi, kondisi dan problema yang sama.

Kata kunci: bank syariah, pembiayaan mudharabah, ketidakadilan

\section{PENDAHULUAN}

Pembiayaan mudharabah atau dikenal dengan istilah qiradh dalam fatwa DSN no. 07 adalah akad kerjasama antara dua pihak di mana pemilik dana (shahibul maal) menyediakan seluruh modal sedangkan pihak kedua (mudharib) bertindak selaku pengelola dan keuntungan usaha dibagi di antara mereka sesuai dengan kesepakatan yang dituangkan dalam kontrak. Kontrak mudharabah merupakan bentuk penolakan terhadap sistem bunga yang diterapkan oleh bank konvensional. Bunga merupakan perbuatan riba yang diharamkan dalam al Quran karena riba bukanlah meringankan beban orang yang dibantu dalam hal ini mudharib tetapi merupakan tindakan yang memperalat dan memakan harta orang lain tanpa melalui jerih payah dan berisiko serta kemudahan yang diperoleh orang kaya di atas kesedihan orang miskin (Qardhawi, 1997:184).

Pembiayaan mudharabah merupakan salah satu jenis produk unggulan dari bank syariah, namun produk unggulan tersebut masih belum menunjukkan perkembangan yang signifikan. Sistem keuangan Islam yang berkembang saat ini hanya sebagian saja dan tidak sepenuhnya. Selain itu, visi dan misi yang sedang dipraktikkan tidak muncul, karena tidak adanya lembaga yang meminimalkan risiko terkait dengan moral hazard dan konflik keagenan (Chapra, 2008). Risiko bank lainnya yang ditimbulkan apabila menerapkan produk mudharabah adalah pihak pemilik modal menanggung kerugian modalnya dan pelaksana proyek menanggung kerugian tenaga. Dengan kata lain, masing-masing pihak yang melakukan kerjasama dalam sistem berpartisipasi dalam kerugian dan keuntungan (Muhammad, 2000). 
Banyak kritikan tentang praktik pembiayaan mudharabah saat ini, salah satunya dikemukakan oleh Kamla (2009) yang mengatakan bahwa, produk mudharabah tidak adil karena tidak pro kemiskinan. Dari hasil penelitan Kamla (2009) mengungkapkan bahwa produk mudharabah yang ada saat ini hanya merupakan replikasi, modifikasi atau inovasi dari konvensional yang di dalamnya masih terselubung bunga dan tanpa mempertimbangkan nilai-nilai keadilan. Hal ini dikarenakan, perbankan syariah tidak menerapkan sistem profit and loss sharing, akan tetapi menggunakan konsep yang dianut oleh perbankan konvensional, yaitu menerapkan sistem bunga yang besarnya ditetapkan pada saat awal akad. Selain itu, ada beberapa ketidakseimbangan antara hak pengelola dana dan pemilik dana dalam hal pembagian risiko kerugian usaha. Kerugian usaha pada bisnis yang disepakati ditanggungkan kepada mudharib, bank tidak mau berisiko sama sekali (Kamla, 2009; Presley, 2000).

Maharani (2008) dan Friyanto (2010) juga meneliti tentang implementasi mudharabah. Menurut mereka terdapat agency problem pada pembiayaan mudharabah. Menurut Maharani (2008), secara spesifik agency problem yang terjadi dalam kontrak mudharabah adalah ketika kepentingan enterpreneur/ mudharib dan shahibul maal bertentangan. Pihak shahibul maal dalam kontrak mudharabah tidak diperbolehkan ikut campur dalam masalah pengelolaan usaha sehingga mudharib memiliki informasi privat yang lebih besar dan membuka peluang asimetri informasi. Friyanto (2010) berpendapat bahwa, penyimpangan-penyimpangan atas pembiayaan yang diterima nasabah serta pemberian informasi yang salah kepada bank mengenai usaha yang dijalankan oleh nasabah akan menguntungkan nasabah dan merugikan bank. Alternatif untuk meminimalisir asimetri informasi, yaitu dengan cara menetapkan struktur insentif kepada pelaku usaha (Friyanto, 2010). Namun, ada beberapa kejanggalan yang ditemukan Maharani (2008) pada penerapan mudharabah yang menyebabkan semakin jauh dari prinsip syariah, yaitu penetapan nisbah yang tinggi sehingga bank syariah terkesan lebih riba dari pada konvensional dan seluruh biaya operasional baik notaris, pajak, auditor dibebankan kepada mudharib. Selain itu, Maharani (2008) juga menganggap bahwa, Praktik mudharabah menjauhi prinsip syariah Islam karena tidak amanah. Ketidakamanahan tersebut timbul karena shahibul maal dan mudharib yang bersumber dari sikap risk averse. Shahibul maal kurang amanah dalam menjalankan mudharabah sesuai dengan ketentuan prinsip syariah Islam sementara mudharib kurang amanah dalam mengelola dana pembiayaan sehingga dana dialihkan untuk bidang usaha lain.

Nilai-nilai yang wajib dijunjung tinggi oleh bank syariah yaitu, nilai kejujuran dalam segala bentuk aktivitas atau kegiatan operasional dari sistem perbankan syariah, kepercayaan dari berbagai pihak dan keadilan (Darmawatie, 2008; Fatahullah, 2008). Keadilan dalam konteks ekonomi Islam yang dimaksud Fatahullah (2008) memiliki dua dimensi yaitu, pemodal berhak mendapatkan imbalan yang 
sepadan dengan risiko dan debitur mendapatkan modal usaha yang butuhkan dan bagi-hasil. Menurut mereka sistem bagi-hasil merupakan ekonomi yang riil, bukan hanya permainan kertas dan angka.

Mulawarman (2011) berpendapat bahwa, bank syariah tidak ada bedanya dengan bank konvensional, karena banyak dari praktisi perbankan syariah hanya berfokus pada laba bukan maslahat. Hal yang sama dikemukakan oleh Nurohman (2009) yang mengatakan, fenomena kemajuan sistem mudharabah dalam perbankan syariah saat ini perlu dicermati, karena yang perlu diteliti lebih jauh adalah sistemnya, yang bermuara pada kesesuaian prinsip-prinsip syari'ah dalam mekanisme kerjanya, karena apabila hanya berlandaskan pada kesiapan, kemapanan ekonomi dan kredibilitas kejujuran masyarakat, sementara prinsip syari' ah ditinggalkan, berarti sama saja. Alternatif yang mungkin dapat dilakukan menurut Nurohman (2009) adalah melakukan non institusionalisasi mudharabah, melalui lembaga jasa murni sosial non profit seperti Baitul Maal, atau lembaga perbankan syariah sendiri dengan persyaratan yang sangat bertentangan dengan karakter bank itu sendiri.

Pendapat berbeda dikemukakan oleh Endarwanto (2011) tentang praktik mudharabah. Endarwanto mengemukakan bahwa, PSAKS dinilai sulit untuk diterapkan secara komprehensif oleh perbankan syariah. Hal ini disebabkan, PSAKS yang berlaku harus dapat dikaji dampaknya kepada unit bisnis, karena yang menerbitkan PSAKS kebanyakan memang berbicara dari sisi akademisi.

Berdasarkan latar belakang di atas, banyak pro kontra terhadap praktik pembiayaan mudharabah saat ini, maka dari itu penelitian ini ingin mengungkap fenomena ketidakadilan dalam praktik pembiayaan mudharabah. Jenis penelitian ini adalah kualitatif dengan pendekatan fenomenologi transendental Husserl yang bertujuan untuk mengungkap fenomena ketidakadilan dalam pembiayaan mudharabah dan menganalisis serta mendiskripsikan penyebab terjadinya ketidakadilan tersebut.

\section{METODE PENELITIAN}

Metodologi yang digunakan dalam mengungkap fenomena ketidakadilan dalam pembiayaan mudharabah adalah pendekatan fenomenologi transendental Husserl. Pemilihan metodologi interpretif dengan pendekatan fenomenologi transendental dalam mengungkap ketidakadilan dalam pembiayaan mudharabah dilatarbelakangi oleh keinginan mengungkap bagaimana fenomena yang ada tersebut apa adanya berdasarkan perspektif informan. Pendekatan yang cocok untuk mendapatkan hal tersebut adalah fenomenologi transendental Husserl yang di-extended dengan menekankan pada kesadaran informan akan keberadaan realitas sebagai "objek". Moustakas (1994; 34) menjelaskan bahwa: "It is transcedental because it moves beyond the everyday to the pure ego in which everything is perceived freshly, as if for the first time." 
Pemaparan di atas dapat diartikan, disebut transendental karena bebas dari persepsi yang lain, sehingga semuanya dianggap "fresh" dari narasumber dan seolah-olah untuk pertama kali diterima. Moustakas (1994; 26) mengasumsikan bahwa fenomenologi transendental berpedoman pada konsep Huserl, yaitu epoche yang membutuhkan eleminasi atas dugaan atau prasangka dan pengetahuan yang terdahulu. Selain itu, epoche menurut Moustakas $(1994 ; 33)$ yaitu:

"Epoche requires a new way of looking at things, a way that requires that we learn to see what stands before our eyes, what we can distinguish and describe"

Epoche memerlukan cara baru dalam memandang sesuatu, cara yang mengharuskan kita belajar untuk melihat apa yang berdiri di hadapan kita, apa yang dibedakan dan dijelaskan tanpa ada pengaruh dari faktor lain. Epoche berarti sesuatu yang murni diperoleh dari seorang peneliti dari suatu fenomena. Pada Epoche, pemahaman sehari-hari, penilaian dan pengetahuan terhadap sesuatu tersebut disisihkan terlebih dahulu. Fenomenologi transendental menekankan atas keberadaan realitas sebagai "objek". Penting bagi peneliti menghadirkan kesadaran aktif dalam menagkap dan merekonstruksi suatu gejala. Fenomena ini akan mencari makna dan hakikat dari penampakan, dengan intuisi dan refleksi dalam tindakan sadar melalui pengalaman. Hal tersebut pada akhirnya akan dapat membawa kepada ide, konsep, penilaian dan pemahaman yang hakiki (Kuswarno, 2009:46).

Menurut Husserl, dengan fenomenologi kita dapat mempelajari bentuk-bentuk pengalaman dari sudut pandang orang yang mengalaminya secara langsung, seolaholah mengalaminya sendiri. Semuanya itu bersumber dari bagaimana seseorang memaknai objek dalam pengalamannya (Kuswarno, 2009:10). Husserl melalui tulisannya yang berjudul Logical Investigations, menggabungkan antara psikologi diskriptif dengan logika. Husserl mengistilahkan proses kesadaran yang disengaja (objek real) dengan noesis dan sedangkan noema untuk objek yang disadari (objek dalam persepsi). Selain itu, Huserl menggunakan epoche untuk term bebas dari prasangka. Dengan epoche ini kita menyampingkan penilaian, bias dan pertimbangan awal yang kita miliki dalam suatu objek (Kuswarno, 2009:48).

Singkatnya, fenomenologi sebenarnya merupakan pertemuan antara kejadian dan kesadaran. Alat utama penelitian fenomenologi adalah intuisi dan refleksi yang subyektif atas hasil analisis intensional dari subjek yang dilakukan dengan proses epoche dengan menyertakan ekstensi atau proses pemahaman, yaitu dengan memperhatikan makna hal-hal yang bersifat subyektif di balik apa yang terlihat. Ada beberapa langkah-langkah yang perlu dilakukan dalam metode fenomenologi adalah sebagai berikut: intentional analysis, epoche, dan eidetic reduction.

Penelitian ini dilakukan pada BMT Al-Rifa'i yang ada di Kabupaten Malang serta bank syariah yang bekerja sama dengan BMT. Alasan dipilihnya situs ini antara lain dikarenakan situs ini mempunyai pengalaman melakukan transaksi pembiayaan mudharabah. Pertimbangan lainnya adalah informan kunci diperoleh 
peneliti dari bantuan salah satu teman di MSA yang pernah bekerjasama dengan BMT Al-Rifa'i. Pemilihan informan dan latar belakang yang sesuai juga sangat penting. Latar belakang historis informan dan faham tentang prinsip syariah dalam perbankan menjadi pokok pertimbangan. Dengan pertimbangan kondisi tersebut, maka dipilihnya ketiga informan tersebut dirasa mampu untuk memberikan informasi mendalam dan sesuai dengan konteks penelitian. Informan yang akan dijadikan sumber data dalam kajian ini berjumlah tiga orang yang terlibat langsung dalam kontrak mudharabah yaitu pengelola BMT dan pengurus pondokan Al-Rifa'i selaku mudharib serta manager marketing bank syariah selaku pihak yang bertanggung jawab dalam proses transaksi mudharabah dengan BMT Al-Rifa'i. Alasan pemilihan tiga informan dalam penelitian ini, karena tiga informan tersebut telah mengalami langsung situasi atau kejadian yang berkaitan dengan topik penelitian yaitu melakukan beberapa kali pembiayaan mudharabah dengan perbankan syariah, selain itu informan mampu menggambarkan kembali fenomena yang telah dialaminya, serta bersedia untuk terlibat dalam kegiatan penelitain yang mungkin membutuhkan waktu yang lama, dan bersedia untuk diwawancara dan direkam aktivitasnya selama wawancara atau selama penelitian berlangsung. Sehingga menurut peneliti, informan yang dipilih sudah cocok atau pas dengan fokus yang akan diteliti.

Informan yang dipilih dalam penelitian ini adalah Bapak Rofiq, Bapak Wachid, serta Bapak X selaku manager marketing bank syariah. Informan yang pertama adalah Bapak Rofiq yang merupakan sekretaris koppontren Al-Rifa'i sekaligus pencetus ide pendirian BMT pada Pondok Pesantren Al Rifa'ie. Bapak Rofiq merupakan warga asli Sidoarjo yang telah lama mondok di Singosari sejak tahun 1985, pada tahun 1989 beliau merupakan salah satu pemikir berdirinya yayasan Al-Rifa'i dan bertindak sebagai sekretaris yayasan. Pak Rofiq merupakan salah satu pendiri dari organisasi perkumpulan BMT di Jawa Timur. Informan selanjutnya adalah Bapak Wachid selaku manajer BMT Al-Rifa'i. Beliau merupakan jebolan dari Pondok Pesantren Al-Hikam dan menempuh S1 Jurusan Pendidikan Agama Islam pada perguruan tinggi Islam di Malang, yang kemudian dipercaya untuk mengembangkan BMT Al-Rifa'i. Selain bekerja di BMT Al-Rifa'i, beliau juga dipercaya untuk mengelola perpustakaan di pesantren Al-Hikam. Informan yang terakhir adalah Bapak X, selain bekerja sebagai manager marketing salah satu bank syariah. Bapak X dipilih peneliti sebagai informan, untuk mengkonfirmasi serta mengecek kebenaran data dari hasil informasi yang didapat dari mudharib, yaitu BMT AlRifa'i. Selain itu, dipilihnya Bapak X, karena Bapak X terlibat langsung dalam perikatan pembiayaan mudharabah antara BMT Al-Rifa'i dengan Bank Syariah X. Bapak X juga memiliki kemampuan accounting. Selain terlibat langsung dalam kontrak mudharabah, masing-masing informan juga mempunyai pengalaman yang cukup lama dan menguasai di bidangnya, yaitu minimal dua tahun. Oleh karena itu keberadaan informan ini memungkinkan peneliti memperoleh informasi yang komprehensif, yang merefleksikan kesadaran pemahaman para informan tersebut 
tentang ketidakadilan dalam praktik pembiayaan mudharabah, serta dapat memahami persoalan-persoalan seputar isu yang terkait dalam praktik pembiayaan mudharabah.

Dalam penelitian, uji keabsahan data umumnya ditekankan pada uji validitas dan reliabilitas. Validitas merupakan derajat ketepatan antara data yang terjadi pada objek penelitian dengan daya yang dapat dilaporkan oleh peneliti. Sedangkan reliabilitas oleh Stainback (1988) yang dikutip Sugiyono (2010:267), sering didefinisikan sebagai derajat konsistensi dan stabilitas data atau temuan pada penelitian. Penelitian ini menggunakan triangulasi untuk menguji derajat kepercayaan. Triangulasi diartikan sebagai pengecekan data dari berbagai sumber dengan berbagai cara, dan berbagai waktu (Sugiyono, 2010:273). Dengan demikian terdapat triangulasi sumber, triangulasi teknik pengumpulan data, dan triangulasi waktu (Sugiyono, 2010: 274). Penelitian ini lebih menekankan pada triangulasi sumber dan waktu, triangulasi sumber dilakukan peneliti dengan cara mengeksplorasi lebih dalam dengan mendapatkan penjelasan langsung dari informan kunci yakni yang terlibat dalam proses perikatan pembiayaan mudharabah yaitu BMT Al-Rifa'i selaku mudharib, kemudian peneliti melakukan pengecekan ulang dengan cara mengkonfirmasi langsung kepada bank syariah yang bekerja sama dengan BMT Al-Rifa'i. Dengan cara ini peneliti dituntun dalam mengumpulkan data agar menggunakan berbagai sumber data yang berbeda. Cara ini akan menghasilkan data yang teruji artinya data sejenis yang diperoleh dari informan kunci dapat dibandingkan dengan data yang berasal dari sumber lain (informan pendukung dan dokumen pendukung lainnya).

Triangulasi waktu dilakukan peneliti dengan cara, peneliti meminta informan untuk menjelaskan lagi tentang fenomena tersebut pada waktu yang berbeda. Apabila hasil uji menghasilkan data yang berbeda, maka akan dilakukan lagi wawancara dengan topik/tema yang sama (dengan redaksi yang berbeda) secara berulangulang sehingga sampai menemukan kepastian atau kesamaan datanya. Pada kesimpulannya, triangulasi sudah dilakukan peneliti, sehingga informasi atau data yang didapatkan valid untuk dilakukan analisis dan sintesis.

\section{HASIL DAN PEMBAHASAN}

Bank syariah adalah lembaga keuangan yang berpijak di atas kaidah syariah. Sehingga sebagai lembaga yang mengadopsi nilai-nilai Islam, maka bank syariah harus selalu menjunjung tinggi nilai-nilai image spiritual kepada masyarakat. Image spiritual ini diperlukan agar diferensiasi antara bank syariah dengan bank konvensional dapat terlihat. Bukan hanya rekayasa syariah atau produk riba kemasan syariah.

Dalam praktik mudharabah yang ada saat ini sebelum melakukan kontrak, Bank Syariah X melakukan seleksi mudharib yang sangat ketat, yaitu lebih fokus kepada mudharib yang merupakan lembaga keuangan seperti BPRS dan BMT. Hal ini seperti yang diungkapkan Bapak X sebagai berikut: 
"Penyaluran kita sebetulnya bersyarat, kita mengarahkan pada nasabah kita untuk murabahah dan agar searah dan sinergi dengan kita, untuk mempermudah proses perhitungan bagi-hasil, tapi kita bisa memastikan bahwa ini, sama BPRS atau BMT disalurkan ke murabahah, walaupun kita juga tidak intervensi nasabahnya yang mudharabah sapa saja, atau sama mereka disalurkan ke produk lain, terserah mereka tapi kita menghitungnya seperti produk murabahah."

Pernyataan Bapak X di awal tersebut, tersimpan makna bahwa praktik pembiayaan mudharabah saat ini masih lebih condong kepada lembaga keuangan saja, belum mengarah kepada individu. Kebijakan ini diambil oleh bank untuk mempermudah perhitungan bagi-hasil diawal, yaitu dengan menggunakan asumsi margin murabahah. Dengan kata lain apabila bukan termasuk lembaga keuangan seperti BMT atau BPRS, BSX tidak dapat menyetujui permohonan mudharabah yang diajukan, walaupun sebenarnya alasan menggunakan perhitungan dengan menggunakan margin murabahah hanya sebagai "akal-akalan" bank syariah saja, karena pada dasarnya tujuan bank syariah adalah mensiasati agar bisa melaksanakan produk mudharabah, tapi keuntungannya sudah bisa diprediksi dari awal. Pernyataan tersebut juga menjelaskan bahwa bank tidak berani menerima risiko, sehingga bank akan bertindak hati-hati dengan cara pilih kasih, yaitu hanya lembaga keuangan saja yang diberi pembiaayaan, hal ini dilakukan bank syariah untuk mempermudah proses perhitungan bagi-hasil dengan asumsi margin murabahah.

Kemudian peneliti mencoba mengerucutkan sebagai bentuk epoche dengan bertanya:"Apakah selama ini yang didanai hanya lembaga keuangan saja? Untuk pengusaha baru bagaimana?" Bapak X segera menjawab:

"Memang yang kita danai saat ini untuk mudharabah hanya BPRS, koperasi syariah, BMT. Untuk modal kerja menggunakan musyarakah. Memang untuk non lembaga kita tidak pernah menggunakan mudharabah. Untuk usaha baru shahibul maal tetap berfikir panjang untuk membiayai, keuntungan yang didapat kecil mba."

Dari pernyataan Bapak X tersebut, tersirat bahwa, profit menjadi tonggak utama dalam bank syariah, sehingga apapun produk yang digunakan, orientasinya hanya pada keuntungan minimal yang harus didapatkan bank.

Eideitic reduction yang dapat peneliti abstraksikan dari studi fenomenologi terhadap pernyataan beberapa informan di atas adalah saat ini bank syariah masih berpikir konvensional, sehingga orientasi bisnis menjadi tiang utama dalam setiap praktiknya. Bank syariah hanya membiayai mudharabah dari lembaga keuangan saja, pengkategorian mudharib seperti ini menghilangkan unsur keadilan yang ada dalam BSX, karena fasilitas mudharabah hanya diberikan kepada nasabah lembaga keuangan saja. Meskipun ini tidak melanggar syariah, karena menyangkut pilihan kebijakan, maka dapat dipastikan bahwa perbankan syariah akan melestarikan status quo akses perbankan konvensional, yaitu hanya strata masyarakat atas saja yang dapat menikmati fasilitas perbankan. 
Setelah tahapan pengkategorian mudharib, bank melakukan tahapan selanjutnya, yaitu pembuatan akad. Akad dalam pembiayaan mudharabah adalah kesepakatan dalam suatu perjanjian antara dua pihak atau lebih untuk melakukan dan atau tidak melakukan perbuatan hukum tertentu. Akad merupakan cara yang di ridhoi Allah dan harus ditegakkan isinya. Mardani (2012:71) mengemukakan bahwa Akad (Ikatan, keputusan, atau penguatan) atau perjanjian atau transaksi dapat diartikan sebagai kemitraan yang terbingkai dengan nilai-nilai syariah. Ditinjau dari segi aqidah yang menentukan keabsahannya suatu akad bukanlah pernyataan redaksi, melainkan niat sebenarnya yang mencerminkan tujuan yang akan dicapai. Salah satu poin penting yang ada dalam akad mudharabah adalah besarnya prosentase nisbah yang disepakati kedua belah pihak.

Prosentase nisbah bagi-hasil pada praktiknya, dihitung oleh bank dari perhitungan keuntungan minimal yang harus diperoleh bank (expected yield). Dalam hal ini yang bisa ditawar adalah keuntungan bank yang telah di mark up. Akan tetapi, apabila telah ditentukan keuntungan minimal yang harus dicapai bank, prosentase nisbah mengikuti dan sudah tidak ada tawar-menawar lagi. Fenomena ini terlahir dari noema awal yang dikemukakan mudharib sebagai berikut:

"Memang sudah ada kesepakatan atau ijab qabul dengan bank, tapi itupun sebenarnya terpaksa, kita tidak ada pilihan lain, karna jawaban bank pasti "system kami seperti ini”

Pernyataan tersebut menggambarkan sebuah noema bahwa ada kesepakatan tentang prosentase nisbah, walaupun terpaksa. Dalam hal ini sistem bank syariah dalam menjalankan aktivitasnya masih berfokus pada bagaimana mencapai keuntungan yang telah ditarget. Menurut Bapak Wachid saat awal dilakukannya akad mudharabah, bank telah membuat laporan cash flow "akal-akalan" untuk menghitung proyeksi keuntungan pengelola usaha. Dari laporan cash flow tersebut akan muncul prosentase minimal keuntungan yang harus didapatkan bank tiap periodenya. Penetapan inilah yang membuat BMT merasa terdzalimi. Fenomena ini terlahir dari noema (objek yang dipersepsikan dan dijelaskan oleh informan) di mana BMT harus membayar angsuran yang tetap tiap bulannya. Hal ini terlihat dari pernyataan Bapak Wachid sebagai berikut:

"Pembayaran angsuran bulanan sudah ditentukan di awal, sekian... sekian... jadi mereka tidak mau tahu apakah dana itu yang nanti kita kelola rugi atau tidak." "Yang jelas yang buat cash flow itu bukan kami, tapi pihak bank, "Cash flownya bank kalo dihitung-hitung jauh hitungan bank sama BMT. Kalo di BMT kan laba ruginya, kalo di bank labanya saja. Biayanya ga masuk."

Noema-noema diatas menyatakan bahwa bank syariah membuat cash flow "akal-akalan" demi memastikan keuntungan yang akan diperoleh bank. Menurut mudharib cash flow yang dibuat bank syariah ini, apabila dilihitung keuntungannya yang dibagi dengan bank, jumlahnya hampir sama dengan bunga bank. Dari cash flow tersebut, akan muncul proyeksi keuntungan untuk menghitung angsuran 
mudharib secara tetap tiap bulannya. Peneliti juga melakukan konfirmasi tentang nisbah bagi hasil kepada BSX. Hasil konfirmasi dengan bapak X tertuang seperti di bawah ini:

"Kalo sudah masuk nisbah sudah tidak ada tawar menawar lagi, tawar menawarkan pada saat proyeksi pendapatan tadi. Karna nisbah kan muncul dari proses asumsi yang sebelumnya. Jadi proses tawar menawarnya itu ya saat proyeksi tadi. Bahwasannya saat nisbah itu sebenernya ndak pengaruh. Cuman nanti pengaruhnya pada saat realisasi."

Untuk kejelasan tentang ekspektasi yield, peneliti juga melakukan konfirmasi langsung, hasil dari pemaknaan expected yield menurut pihak perbankan syariah adalah sebagai berikut:

"...kalo bank menginvestasikan 100 juta, dalam waktu satu tahun harus memperoleh keuntungan sekian... itulan ekspektasi atau proyeksi yield atau keuntungan yang harus diperoleh minimal oleh bank..."

"Rata-rata tidak sampai $1 \%$ perbulannya, efektifnya rata-rata $15 \%$ pertahun marginnya. Flatnya 7,5 atau 8 sesuai kesepakatan."

"Jadi ada range minimal sekian persen dari kantor pusat. Sehingga untuk menentukan proyeksi yield atau keuntungan yang ingin didapat dalam setahun itu ada. Jadi sebisa mungkin kita menjual yang pas, tidak terlalu mahal, tidak terlalu murah, dan itu disepakati."

"Untuk proyeksi yield, memang ada tawar menawar, biasanya kita mark up dulu sih, tapi kita memiliki limit terendah. Sama kayak orang jualan gitu mbak.. lawong di bank itu juga dagang lo mbak, cuman kita menyesuaikan saja, kan ga mungkin kita jual sama dengan belinya, logikanya begitu."

Dari hasil konfirmasi tersebut menggambarkan bahwa, bank syariah mempunyai kebijakan dalam menentukan "range minimal" keuntungan yang ingin didapat dalam setahunnya. Bank syariah menganggap bahwa pembiayaan mudharabah ibarat orang "dagang", jadi pihak bank berusaha sebisa mungkin menjual dengan harga yang pas, selama itu disepakati. "Kesepakatan" ini menjadi patokan bank syariah. Walaupun bank syariah menetapkan keuntungan yang besar tiap bulannya, selama ini disepakati, perjanjian mudharabah ini akan sah-sah saja menurut pihak bank.

Mekanisme perhitungan bagi-hasil yang diterapkan di dalam Bank Syariah X yaitu dengan menggunakan perhitungan margin murabahah dan juga oleh keuntungan minimal bank yang harus diperoleh tiap tahunnya. Besaran keuntungan minimal yang ditetapkan bank rata-rata tidak sampai $1 \%$ tiap bulannya. Secara garis besar, yang menjadi acuan perhitungan bagi-hasil oleh bank adalah besar pinjaman dikalikan keuntungan minimal yang diinginkan bank dan jangka waktu pinjaman. Besarnya expected yield tersebut pertahunnya $15 \%$ pa effective. Perhitungan effective yang dimaksud oleh Bapak $\mathrm{X}$ adalah sebagai berikut: 
"Pengakuan pendapatan lebih besar antara pokok dan margin berbeda terus, Tapi angsurannya tetap. Jadi kita sudah tidak mempermasalahkan laporan yang dibuat BMT, karena perhitungannya dari margin Murabahah."

Dari pernyataan tersebut bank memiliki keuntungan minimum yang harus dicapai, dan itu sudah diprediksi dari awal. Dalam hal ini perhitungan keuntungan bagihasil yang dilakukan bank tanpa melihat laporan keuangan mudharib, karena perhitungan pendapatan bagi-hasil diperoleh bank dari margin murabahah, alasan bank menggunakan perhitungan keuntungan dari margin murabahah adalah bank menganggap mudharib menyalurkan modalnya dengan cara transaksi murabahah, sehingga dapat dihitung keuntungannya.

Noesis (pemahaman subyektif informan) dari beberapa noema tersebut diatas adalah perhitungan bagi-hasil yang dihitung oleh bank syariah sama dengan bunga. Hal ini diperoleh dari keterangan Bapak X yang menerangkan tentang ekspektasi yield seperti di bawah ini:

"...kalo bank menginvestasikan 100 juta, dalam waktu satu tahun harus memperoleh keuntungan sekian... itulah ekspektasi atau proyeksi yield atau keuntungan yang harus diperoleh minimal oleh bank..."

"Kalo sudah masuk nisbah sudah tidak ada tawar menawar lagi, tawar menawarkan pada saat proyeksi pendapatan tadi. Karna nisbah kan muncul dari proses asumsi yang sebelumnya. Jadi proses tawar menawarnya itu ya saat proyeksi tadi. Bahwasanya saat nisbah itu sebenernya ndak pengaruh. Cuman nanti pengaruhnya pada saat realisasi."

Dari keterangan Bapak X dapat diambil kesimpulan bahwa, prosentase nisbah muncul setelah perhitungan keuntungan minimal yang harus diterima oleh bank. Hal ini mengindikasikan bahwa keuntungan yang harus diterima oleh bank sama dengan bunga dan hal ini merupakan riba. Kemudian peneliti mencoba mengerucutkan sebagai bentuk epoche dengan bertanya: "Apakah dengan menggunakan asumsi margin murabahah termasuk kategori syariah pak?" dengan ragu-ragu Bapak X menjawab:

"Ya... sebebetulnya kalo kembali ke aspek syariah memang kurang. Cuman dari rasio perhitungan yang bisa kita logikakan dan masuk akal adalah proyeksi perhitungan objek bagi-hasil yaitu dengan asumsi bagi-hasil murabahah. Kalo yang riil nasabah buat laporan per bulan, lalu dihitung bagi-hasilnya. Ga nutut tenaganya mb."

Dari keterangan Bapak X di atas, sebenarnya Bapak X sadar bahwa apa yang dipraktikkan selama ini masih jauh dari syariah. Akan tetapi pada praktiknya tetap saja dilaksanakan, hal ini dikarenakan orientasi keuntungan masih dominan dalam perbankan syariah.

Abstraksi esensi dari korelasi antara noema dan noesis di atas adalah adanya riba (bunga) dalam perbankan syariah. Bank menetapkan kebijakan kepada mudharib angsuran tetap tiap bulannya, karena bank memiliki range keuntungan 
minimal yang harus didapat. Angsuran tetap yang dimaksud oleh mudharib yaitu tiap bulannya bank sudah menentukan berapa besaran keuntungan yang akan diperoleh bank dan berapa angsuran pokok yang harus dibayar mudharib tiap bulannya. Ada beberapa dampak apabila menentukan keuntungan di awal sebagai patokan perhitungan angsuran tiap bulannya. Permasalahan muncul saat perhitungan berdasarkan selisih antara hasil yang diharapkan (expected return) dengan hasil nyata (actual return). Pada angsuran pertama, mungkin tidak masalah, tetapi pada angsuran berikutnya menjadi problem. Karena sesungguhnya modal pinjaman awal telah terkurangi oleh cicilan nasabah pada bulan-bulan sebelumnya. Sehingga menjadi kurang adil ketika nasabah mengangsur dengan besaran yang sama dari sebuah modal yang berbeda (susut). Estimasi maupun prakiraan dan prediksi yang dijadikan dasar perhitungan keuntungan bukan dari usaha riil memiliki keserupaan dengan perhitungan bunga bank atas modal yang jauh-jauh hari bisa diketahui kisaran pasti besaran nilainya.

Penetapan sistem pembayaran dengan flat ini menunjukkan bahwa bank syariah selalu menganggap bahwa usaha nasabah itu selalu mendatangkan keuntungan. Walaupun kenyataannya bisa sebaliknya, sistem flat melalui bargaining ataupun langsung kebijakan dari bank, telah menjadikan bank nampak kurang dapat ambil peduli dengan apa yang menimpa usaha nasabah. Apakah nasabah mendapatkan keuntungan atau tidak, ia harus memberikan bagi-hasil kepada bank. Sistem ini memang dapat membuat nasabah untung besar ketika iklim usaha baik, sebaliknya ketika iklim kurang kondusif, nasabah bisa merugi. Namun kerjasama mudharabah bukanlah kerjasama gambling seperti itu. Mudharabah lebih berorientasi pada solidaritas dan kebersamaan. Jika usaha dari mudharib mendapatkan keuntungan maka bank akan menerima keuntungan, akan tetapi jika mudharib mengalami kerugian, maka bank pun siap menerima kerugian. Hal ini sebenarnya yang membedakan bank syariah dengan sistem ekonomi lain, bahwa sistem perbankan syariah tidak enggan berbagi kerugian, tidak hanya spekulasi dan semata-mata mencari keuntungan. Namun kondisi-kondisi tersebut tidak berlaku dalam praktik mudharabah bank syariah. Bank tidak mau menanggung kerugian jika usaha mengalami kegagalan atau kerugian. Jika terjadi kerugian usaha, niscaya bank akan meminta kembali modal yang telah ia kucurkan dengan utuh. Fenomena "Bank tidak mau menerima kerugian ini terlahir dari noema-noema yang dinyatakan oleh pernyataan Bapak Wachid berikut ini:

"...kalo ada risiko mudharibnya yang nanggung, pernah kita mudharabah 400 juta dibawa lari saat membiayai proyek tebu. Bank ga mau tau, mereka tahunya akad sekian, angsuran sekian...”

Dari pengalaman Bapak Wachid tersebut, menggambarkan bahwa apabila mudharib mengalami suatu kerugian dalam menjalankan usahanya, bank tidak berani mengambil risiko. Mudharib tetap harus mengangsur sesuai kesepakatan 
diawal akad mudharabah. Bapak Wachid mengungkapkan perlakuan BSX saat mudharib mengalami kerugian seperti di bawah ini:

"...bank sudah tahu dan tidak mau tahu. lalu kita minta perpanjangan.. oke diperpanjang. Makanya saya kemarin minta perpanjangan, akhirnya diperpanjang selama tujuh tahun, yang minta saya, tapi ya.. membuat akad baru sisa dari pinjaman, dan dikenakan administrasi lagi, karena margin dihitung ulang, lebih sedikitlah, kan pokoknya berkurang."

Pernyataan Bapak Wachid di atas, tersirat kekecewaan yang mendalam terhadap bank syariah, khususnya apabila mudharib mengalami kerugian usaha. Saat mudharib mengalami kerugian, bank tidak mau tahu, mudharib harus mengangsur sesuai angsuran yang ditetapkan diawal.

Dalam penelitian ini, terdapat noema-noema tentang fenomena ketidakadilan dalam akad mudharabah. Noema yang ditangkap dalam penelitian ini adalah saat mudharib mengalami masalah dalam usahanya, bank tidak mau tahu, mudharib harus tetap mengangsur sesuai dengan ketentuan di awal. Noesis (pemahaman subyektif informan) dari noema tersebut adalah bahwa bank tidak mau ikut menanggung kerugian walaupun mudharib tanpa disengaja mengalami kegagalan usaha. Hal ini diperkuat oleh keterangan Bapak X yang menjelaskan tentang kerugian yang ditanggung shahibul maal sebagai berikut:

"Yang dibagi itu hanya keuntungan saja. Yang diketahui selama ini kan mudharabah tanggung untung, tanggung rugi. Tapi yang dibagi di sini adalah keutungannya saja, kalo untung ya keuntungannya itu yang dibagi, tapi kalo rugi, ya rugi, tidak ada yang dibagi. Terkait dengan pinjamannya ya tetap."

"Bank kan juga ga mau rugi mbak..."

Dari pernyataan Bapak X di atas, terlihat bahwa pihak bank tidak mau berbagi kerugian apabila mudharib mengalami kerugian. Untuk menghilangkan risiko kerugian sedini mungkin, sebelum kontrak perjanjian disepakati, bank meminta jaminan asset/modal dari nasabah pelaku usaha yang selanjutnya akan dijadikan sebagai instrumen pembayaran modal pinjaman jika terjadi kerugian atau kegagalan usaha. Hal ini menjadi indikasi bahwa akad antara perbankan dengan nasabah pelaku usaha bukanlah mudharabah, akan tetapi hutang-piutang yang berbunga alias riba. Jika mudharabah tidak menghasilkan suatu keuntungan, si mudharib mengalami dua kerugian, yang pertama adalah kerugian waktu, dan yang kedua harus membayar angsuran yang disepakati di awal.

Kemudian peneliti mencoba mengerucutkan sebagai bentuk epoche dengan bertanya: "Menurut Bapak, apa yang dimaksud bagi risiko apabila mudharib mengalami risiko kerugian? Bapak X lalu menjawab:

"Selama ini kan yang dipahami dalam mudharabah tanggung untung, tanggung rugi. Sebetulnya hanya keuntungannya saja yang dibagi. Kalo rugi ya rugi... terkait pinjamannya ya tetap, ini kurang dipahami." 
Dari noema dan noesis di atas sangat jelas bagi kita bagaimana perbankan syariah menampakkan wajah aslinya dalam pelaksanaan praktek mudharabah, yaitu sama persis dengan apa yang dilakukan oleh bank konvensional. Dimana bank tidak mau menanggung kerugian usaha dan meminta jaminan asset nasabah pelaku usaha. Praktik ini sama persis dengan apa yang dilakukan oleh bank konvensional, hanya berbeda dalam istilah, yang satu bernama mudharabah sementara bank konvensional bernama kredit usaha berbunga.

\section{SIMPULAN}

Penelitian ini dengan pendekatan fenomenologi membawa kepada pemahaman makna dan hakikat ke dalam suatu peristiwa yang nantinya mengerucut pada satu kesimpulan. Dari temuan-temuan yang ada, implementasi pembiayaan mudharabah mengandung beberapa unsur ketidakadilan. Ketidakadilan lawan dari kata adil. Adil menurut Engineer (1999:59-71) mengandung makna penyamarataan (equalizing) dan kesamaan (levelling). Qist mengandung makna distribusi, angsuran, jarak yang merata, dan juga keadilan, kejujuran dan kewajaran. Sehingga dari kedua kata tersebut dapat diambil kesimpulan, keadilan menurut Engineer (1999) adalah 'distribusi yang merata', termasuk distribusi materi, dan dalam kasus tertentu, penimbunan harta diperbolehkan asal untuk kepentingan sosial. Yang dimaksud keadilan distributif di sini adalah adanya keseimbangan sosial yang harus dijaga. Keadilan sesuai dengan al Quran tidak didasarkan pada kepentingan orang yang kaya dan berpengaruh. Muthahari (2009:60-68) menyatakan bahwa keadilan dari kata "adil" yang memiliki arti keseimbangan, persamaan dan non diskriminasi, pemberian hak kepada pihak yang berhak dan pelimpahan wujud berdasarkan tingkat dan kelayakan". Pemikir keadilan yang lainnya adalah Quthb (1994:37), dalam bukunya yang berjudul "Keadilan Sosial", memaparkan bahwa "menurut pandangan Islam, keadilan adalah persamaan kemanusiaan yang memperhatikan pula keadilan pada semua nilai yang mencakup segi-segi ekonomi yang luas". Adil di sini memiliki makna yang dirangkum dari hasil pemikiran para pemikir keadilan di atas yaitu bahwa keadilan merupakan distribusi hak secara proporsional kepada seluruh pihak berhak yang mencakup seluruh aspek kehidupan.

Setidaknya ada tiga bentuk ketidakadilan yang ditemukan peneliti. Ketidakadilan yang pertama yaitu ketidakadilan dalam pemilihan mudharib, karena hanya diperuntukkan kepada lembaga keuangan saja. Kebijakan bank memilih mudharib hanya lembaga keuangan adalah bentuk safe position bank serta untuk mensiasati agar dapat melaksanakan produk mudharabah dengan keuntungan yang sudah bisa diprediksi dari awal.

Ketidakadilan yang kedua adalah perhitungan bagi hasil mudharabah, dipastikan dan ditetapkan di awal kontrak. Memastikan keuntungan di awal mengindikasikan bahwa ada riba (bunga) dalam perbankan syariah, karena bank memiliki range 
keuntungan minimal yang harus didapat. Dalam hal ini, tingkat keuntungan yang ditentukan untuk produk jual beli, juga menjadi cost of fund untuk semua produk, termasuk produk bagi-hasil. Celakanya, hal itu juga dihitung dengan metode per annum. Maka tidak heran jika ada mudharabah dengan bagi-hasil yang dibebankan kepada nasabah setara $20 \%$ per annum. Artinya nasabah sebagai mudharib harus membayar bagi-hasil kepada bank setara $20 \%$ per tahun. Jika nasabah mendapat keuntungan lebih dari itu, ia hanya membayar 20\%-nya, sedangkan jika ia rugi maka ia harus tetap membayar setara itu. Padahal mudharabah adalah produk bagi-hasil yang kondisi pendapatannya tidak fixed, tergantung situasi bisnis.

Pembiayaan mudharabah bukanlah kerjasama yang gambling, akan tetapi pembiayaan mudharabah merupakan lebih berorientasi pada solidaritas dan kebersamaan. Jika untung untung semua, dan apabila mengalami kerugian, pemodal dan pengelola dana juga akan mengalami kerugian, walaupun di sisi material pemodal yang menanggungnya. Di sinilah bedanya sistem bagi-hasil dengan bunga. Selain itu, dengan angsuran tetap seperti ini juga akan mempengaruhi jumlah modal yang digunakan untuk modal kerja. Karena sesungguhnya modal pinjaman awal telah terkurangi oleh cicilan mudharib pada bulan-bulan sebelumnya. Sehingga menjadi kurang adil ketika nasabah mengangsur dengan besaran yang sama dari sebuah modal yang semakin lama semakin berkurang. Penetapan angsuran secara tetap tiap bulan menunjukkan bahwa bank syariah selalu menganggap bahwa nasabah itu selalu mendatangkan keuntungan. Walaupun kenyataannya bisa sebaliknya. Dalam hal ini bank tidak mau menerima kerugian apabila mudharib mengalami rugi, inilah ketidakadilan ketiga yaitu bank menyalahi akad pembiayaan mudharabah yang dibuat oleh bank sendiri. Dimana bank tidak mau menanggung kerugian usaha dan meminta jaminan asset nasabah pelaku usaha.

Selain itu, permasalahan lainnya adalah adanya standard contract atau akad baku yang dibuat oleh bank. Bank menganggap semua mudharib memiliki situasi dan kondisi yang sama. Ada berbagai alasan yang dikemukakan bank terkait akad baku yang dibuat oleh bank, Alasan yang pertama adalah, bank tidak mau ribet dengan akad, dan bank menganggap yang terpenting adalah antara shahibul maal dan mudharib sepakat. Alasan kedua, bank juga menganggap mudharib belum bisa amanah, sehingga bank memilih safe position untuk mengamankan dananya.

Dari berbagai permasalahan di atas, dapat disimpulkan bahwa pembiayaan mudharabah tidak cocok dilakukan di Indonesia, karena terkendali oleh trust. Untuk ke depannya, perlu ada upaya bersama untuk mencari jalan keluar, misalnya menyusun undang-undang bank syariah tersendiri. Hal ini amat penting agar bank syariah dapat menunjukkan ciri khas produknya. Pengembangan produk bukan saja melibatkan sumber daya yang ada dalam penelitian dan pengembangan, tetapi juga sumber daya yang mengerti dan mendalami syariah, karena sumber daya manusia yang ada di bank syariah sekarang ini belum memiliki pengetahuan di kedua bidang itu secara simultan. Untuk itu, perlu dikembangkan sejak dini 
penggabungan pendidikan ilmu duniawi dan ilmu agama sejak dini sekali dan ini harus dilanjutkan ke tingkat berikutnya bahkan sampai tingkat perguruan tinggi, sehingga dikotomi pengetahuan agama dan pengetahuan dunia lama-kelamaan akan menipis. Ini bukan tugas perbankan syariah semata, tapi tugas ummat Islam secara nasional.

\section{DAFTARA PUSTAKA}

Al Quran

Chapra, M.U. 2008. The Islamic Vision of Development in the Light of the Maqasid Al Shari'ah. The Islamic Foundation. Leicester, UK.

Darmawatie. 2008. Implementasi Pendapatan Mudharabah dalam Perspektif Kejujuran dan Keadilan. Tesis Program Magister Akuntansi Brawijaya. Tidak dipublikasikan.

Endarwanto, J. 2011. Sudah Syari'ah Bank Syari'ah? Seperti Katak dalam Tempurung. Ekuitas, Edisi 1 September.

Engineer, A.A. 1999. Islam dan Teologi Pembebasan. Yogyakarta: Pustaka Pelajar.

Fatwa DSN No. 07/DSN-MUI/IV/2000.

Fatahullah. 2008. Implementasi Prinsip Bagi Hasil dan Risiko di Perbankan Syariah. Tesis Program Magister Ilmu Hukum Universitas Diponegoro. Dipublikasikan.

Friyanto. 2010. Analisis Implementasi Pembiayaan Mudharabah dan Risiko-Risikonya. Tesis Program Magister Akuntansi Brawijaya. Tidak dipublikasikan.

Ikatan Akuntan Indonesia. 2009. Pernyataan Standar Akuntansi Keuangan (PSAK) No. 105 Akuntansi Mudharabah.

Kamla. 2009. Critical Insights Into Contemporary Islamic Accounting. Critical Perspectives on Accounting. 20. 921-932.

Kuswarno, E. 2009. Metodologi Penelitian Komunikasi, Fenomenologi (Konsep, Pedoman, dan Contoh Penelitian). Bandung: Widya Padjajaran UNPAD.

Maharani, S.N. 2010. Mereduksi Agency Problem pada Kontrak Mudharabah melalui Bingkai Metafora Amanah, Tesis, Universitas Brawijaya, Malang.

Mardani. 2012. Fiqh Ekonomi Syariah (Fiqh Muamalah). Jakarta: Kencana Media Group.

Moustakas, Clark, E. 1994. Phenomenological Research Methods. Sage Publications, Thousand Oaks California.

Muhammad. 2000. Sistem \& Prosedur Operasional Bank Syariah. Yogyakarta: Universitas Islam Indonesia Press.

Mulawarman, A.D. 2011. Sudah Syari'ahkah Praktik Perbankan Syariah? Tuhan ditinggal di Masjid. Ekuitas, Edisi 1 September.

Presley, J., Abalkhail, M. 2000. How Information Risk Capital Investor Manag The Asymetric Information in Profit Loss Sharing Contracts (PLS). Loughborough University and Imam Mohammad Ibnu Saud Islamic University.

Qardhawi, Y. 1997. Norma dan Etika Ekonomi Islam,Jakarta: Gema Insani Press.

Quthb, S. 2004. Keadilan Sosial dalam Islam. Bandung: Pustaka.

Sugiyono. 2010. Metode Penelitian Kuantitatif, Kualitatif dan R \& D. Bandung: Alfabeta. 